\title{
Spatial variability of methane emissions from Swiss alpine fens
}

\section{Journal Article}

\section{Author(s):}

Franchini, Alessandro G.; Erny, Isolde; Zeyer, Josef

Publication date:

2014-08

Permanent link:

https://doi.org/10.3929/ethz-b-000080357

Rights / license:

In Copyright - Non-Commercial Use Permitted

Originally published in:

Wetlands Ecology and Management 22(4), https://doi.org/10.1007/s11273-014-9338-6 


\title{
Spatial variability of methane emissions from Swiss alpine fens
}

\author{
Alessandro G. Franchini • Isolde Erny • \\ Josef Zeyer
}

Received: 22 May 2013/Accepted: 9 January 2014/Published online: 23 January 2014

(C) Springer Science+Business Media Dordrecht 2014

\begin{abstract}
Wetland ecosystems are a major natural source of the important greenhouse gas methane $\left(\mathrm{CH}_{4}\right)$. Among these ecosystems, fens have been shown to release high quantities of $\mathrm{CH}_{4}$. Data on $\mathrm{CH}_{4}$ emissions from alpine fens are scarce and mainly limited to the United States and China. Therefore, static chambers were used to quantify $\mathrm{CH}_{4}$ emissions from 14 fens located in the Swiss Alps. The aims of this study were to determine the spatial variability of the emissions and to identify potential key factors which influence $\mathrm{CH}_{4}$ turnover. The fens were located at altitudes between 1,800 and 2,600 m a.s.l., the pore water varied from acidic to slightly acidic $(\mathrm{pH}$ 4.5-6.4) and the vegetation was dominated by plants of the genus Carex. In addition, the underlying bedrock was either siliceous or calcareous. Methane emissions ranged from $74 \pm 43$ to $711 \pm 212 \mathrm{mg}$ $\mathrm{CH}_{4} \mathrm{~m}^{-2}$ day ${ }^{-1}$. The type of bedrock, the plant biomass above the water table and the $\mathrm{CH}_{4}$ pore water concentrations at depths from 0 to $20 \mathrm{~cm}$ were the main factors influencing $\mathrm{CH}_{4}$ emissions. Detailed measurements in three selected fens suggested that more than $98 \%$ of the total $\mathrm{CH}_{4}$ emissions are due to plant-mediated transport.
\end{abstract}

A. G. Franchini · I. Erny · J. Zeyer ( $₫)$

Institute of Biogeochemistry and Pollutant Dynamics,

ETH Zurich, Universitätstrasse 16, 8092 Zurich,

Switzerland

e-mail: zeyer@env.ethz.ch
Keywords Greenhouse gas - Wetland · Pore water profile $\cdot$ Dissolved organic carbon

\section{Introduction}

Wetlands are important ecosystems with regard to the global carbon cycle and consequently exert a major impact on climatic change. Wetlands are characterized by waterlogged, anoxic conditions that result in incomplete decomposition of organic material and accumulation of carbon in the form of peat (Lai 2009). The photosynthetically active plants, mosses and algae at the surface function as a sink for atmospheric carbon dioxide. On the other hand, the deeper layers are a source for carbon dioxide and methane $\left(\mathrm{CH}_{4}\right)$ because organic matter is decomposed under methanogenic conditions (Conrad 1996). Wetlands are the largest natural sources of atmospheric $\mathrm{CH}_{4}$, with annual emissions of 100-230 $\mathrm{Tg} \mathrm{CH}_{4}$, representing 20-40\% of estimated global emissions (Denman et al. 2007). This considerable level of uncertainty arises, in part, from site-specific spatial and seasonal variability (Bubier et al. 1995a; Christensen et al. 1995; Bellisario et al. 1999; Joabsson and Christensen 2001; Whalen 2005; Sachs et al. 2010).

Wetlands are diverse and heterogeneous ecosystems characterized as bogs and fens (Whalen 2005), which are mainly distinguished by their dominant water source (Limpens et al. 2008). Bogs are ombrotrophic ecosystems with a low water input from 
precipitation, an acidic and nutrient-poor environment and dominated by bryophytes, such as Sphagnum species, which are slowly decomposed (Moore and Basiliko 2006; Limpens et al. 2008). Minerotrophic fens receive water and nutrients from groundwater, resulting in a more nutrient-rich environment, mainly vegetated by vascular plants that promote the gasexchange between the subsurface and the atmosphere (Rydin and Jeglum 2006). Thus, as a consequence of the fens' minerotrophic condition, higher average water table, and vegetation type, $\mathrm{CH}_{4}$ emissions from fens are generally higher than those from bogs (Whalen 2005). Methane emissions range from 10 to $180 \mathrm{mg} \mathrm{CH}_{4} \mathrm{~m}^{-2}$ day $^{-1}$ and from 30 to $400 \mathrm{mg} \mathrm{CH}_{4}$ $\mathrm{m}^{-2}$ day $^{-1}$ for bogs and fens, respectively (Dise et al. 1993; Bubier et al. 1995b; Bellisario et al. 1999; Chasar et al. 2000).

Most of the studies on $\mathrm{CH}_{4}$ emissions in cold environments have focused on wetlands located in the northern hemisphere (Sebacher et al. 1986; Whalen and Reeburgh 1992; Bubier et al. 1995a; Christensen et al. 1995; King et al. 1998; Bellisario et al. 1999; Waddington and Roulet 2000; Whalen and Reeburgh 2000; Wagner et al. 2003; Saarnio et al. 2007; Sachs et al. 2010), as these ecosystems harbor one third of the global soil carbon (Gorham 1991; Turunen et al. 2002). Alpine wetlands have not been extensively studied and available data are mainly limited to the Rocky Mountains (West et al. 1999; Wickland et al. 2001; Chimner and Cooper 2003) and the Tibetan Plateau (Hirota et al. 2004; Cao et al. 2008; Chen et al. 2009, 2011). Very few reports have dealt with alpine wetlands in the European Alps (Koch et al. 2007; Liebner et al. 2012). Hence, detailed investigations are necessary to accurately estimate the contribution of alpine wetlands to the global $\mathrm{CH}_{4}$ budget (Mast et al. 1998; Koch et al. 2007).

Methane production, oxidation, and transport from the subsurface to the atmosphere are closely linked and depend on a number of environmental factors such as temperature (Bubier et al. 1995a; Heyer et al. 2002; Koch et al. 2007), water table elevation (Freeman et al. 1992; Dise et al. 1993; Christensen et al. 1995), pH (Bubier et al. 1995b) and vegetation type (Schimel 1995; Bellisario et al. 1999; Ström et al. 2003). In order to understand and predict the $\mathrm{CH}_{4}$ cycle in wetlands it is necessary to analyze the impact of each environmental factor on $\mathrm{CH}_{4}$ production, oxidation and transport to the atmosphere (Bridgham et al.
2013). Methane is produced by methanogenic archaea under anoxic conditions, while methanotrophic bacteria in oxic sediment zones use the gas as a carbon and energy source (Conrad 1996).

Temperature is an important factor affecting biologically-mediated processes, and it has been reported that $\mathrm{CH}_{4}$ production is more sensitive than $\mathrm{CH}_{4}$ oxidation to temperature changes (Whalen 2005). In several wetland soils a close relationship between temperature and $\mathrm{CH}_{4}$ emissions has been found, with emissions increasing proportionally to temperature (Bubier et al. 1995b; Heyer et al. 2002; Koch et al. 2007). Water table elevation has been identified as a good parameter to estimate $\mathrm{CH}_{4}$ emissions (Bubier et al. 1995a, b; Koch et al. 2007). The water table has been suggested to affect both $\mathrm{CH}_{4}$ production and $\mathrm{CH}_{4}$ oxidation by regulating the position of the oxic-anoxic interface in the peat (Dunfield et al. 1993; Whalen 2005). Drought conditions have been reported to result in a lower $\mathrm{CH}_{4}$ production, limited to deep anoxic soil layers, while $\mathrm{CH}_{4}$ oxidation during drought was not influenced (Freeman et al. 2002). In addition, the oxic layer resulting from a decrease in the water table might support a higher decomposition of the organic material, influencing the carbon cycle in wetlands (Bardgett et al. 2008). However, the data are contradictory and the correlation between the water table elevation and $\mathrm{CH}_{4}$ emissions was reported to be weak (Bellisario et al. 1999; Trudeau et al. 2013).

Peat acidity can affect $\mathrm{CH}_{4}$ production and oxidation, with lower $\mathrm{pH}$ reducing $\mathrm{CH}_{4}$ production. For example, a significant reduction in $\mathrm{CH}_{4}$ production rates were reported for peat slurries incubated at a $\mathrm{pH}$ of 5.5 compared to incubations at $\mathrm{pH}$ of 7.0 (Valentine et al. 1994). However, partial adaptation of methanogenic archaea and methanotrophic bacteria to suboptimal pH has been observed (Dunfield et al. 1993).

$\mathrm{CH}_{4}$ emissions from wetlands are strongly dependent on vegetation type, as plants influence $\mathrm{CH}_{4}$ production, oxidation, and transport from the subsurface to the atmosphere (Christensen et al. 2003; Ström et al. 2003). A positive correlation between plant productivity, plant biomass and $\mathrm{CH}_{4}$ emission has been reported in different wetlands (Whiting and Chanton 1993; Bellisario et al. 1999; Joabsson and Christensen 2001; von Fischer et al. 2010; Chen et al. 2011).

Many vascular plants in fens have developed air channels in stems, leaves and roots (i.e. aerenchyma) to transport oxygen to submerged organs in anoxic soil 
(Armstrong et al. 1991; Joabsson et al. 1999). As a consequence, the aerenchyma may also act as conduits for $\mathrm{CH}_{4}$ transport to the atmosphere, bypassing the oxic layer where biological $\mathrm{CH}_{4}$ oxidation is taking place (Bellisario et al. 1999; Whalen 2005). Several studies addressing atmospheric $\mathrm{CH}_{4}$ emission therefore focused on wetlands dominated by Carex spp. (Whiting and Chanton 1992; Chasar et al. 2000; Ding et al. 2004). It has been reported that more than $90 \%$ of the $\mathrm{CH}_{4}$ emitted in Carex spp. dominated wetlands passes through their aerenchyma system (Whiting and Chanton 1992). In contrast, in a laboratory study using peat cores dominated by Sphagnum spp. and cores dominated by Juncus spp. lower $\mathrm{CH}_{4}$ emissions were observed from the cores vegetated by vascular plants (Roura-Carol and Freeman 1999). Vascular plants also stimulate $\mathrm{CH}_{4}$ production through secretion of root exudates and provision of plant litter to the methanogenic archaea (Whiting and Chanton 1992). In addition, vascular plants transport oxygen to the rhizosphere which stimulates the activity of methanotrophic microorganisms (Bellisario et al. 1999).

A field survey was conducted to quantify $\mathrm{CH}_{4}$ emissions from fens located in the Swiss Alps. The Swiss Alps are characterized by two main bedrock types (siliceous and calcareous) which are the dominant influence on the soil properties (Lazzaro et al. 2009). Calcareous bedrock is composed of large amounts of $\mathrm{CaCO}_{3}$ that result in a more alkaline soil and a lower availability of nutrients compared to siliceous bedrock.

The specific goals of this study are (i) to assess the spatial variability of $\mathrm{CH}_{4}$ emissions from alpine fens located on siliceous or calcareous bedrock in Switzerland, (ii) to quantify $\mathrm{CH}_{4}$ pore water concentrations of these fens, and (iii) to conduct a statistical analysis in order to relate $\mathrm{CH}_{4}$ emissions to selected environmental factors (e.g. bedrock and vegetation type, plant biomass, soil and air temperature, and dissolved organic carbon [DOC] concentrations).

\section{Materials and methods}

Sampling sites

Fourteen different alpine fens in the Swiss Alps were selected (Fig. 1). The main criteria for choosing these fens were (i) a water table above the soil surface and

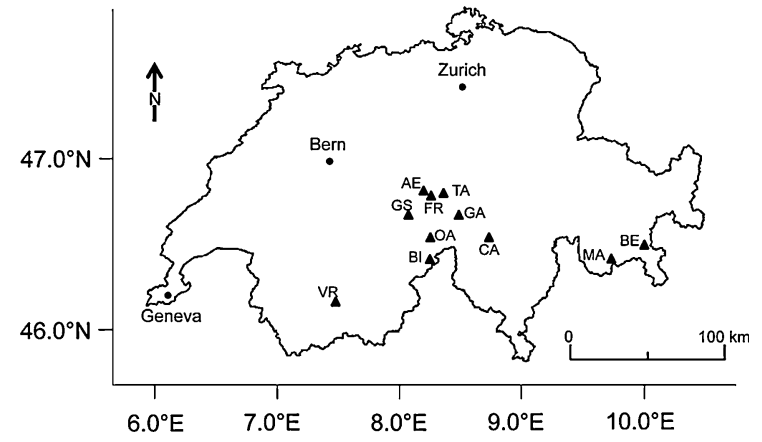

Fig. 1 Location of the selected fens in the Swiss Alps: Aelggi $(A E)$, Bernina $(B E)$, Binntal $(B I)$, Cadagno $(C A)$, Frutt $(F R)$, Göschener Alp $(G A)$, Grosse Scheidegg $(G S)$, Maloja $(M A)$, Oberaar $(O A)$, Tannalp $(T A)$ and Val de Réchy $(V R)$

(ii) a vegetation cover mainly composed of plants of the genus Carex. The 14 alpine fens in this study varied in altitude, bedrock type, yearly mean precipitation, as well as type of plant cover (Table 1). The sites are generally characterized as snow-covered in winter and with a 3-4 month long snow-free summer. The average annual precipitation data at each site was obtained from the CLIMAP database of the Swiss Federal Office of Meteorology and Climatology (http://meteoswiss.ch; Table 1). Altitudes ranged from 1,800 to 2,600 m a.s.l.; six fens were located on calcareous bedrock and eight fens on siliceous bedrock. Most fens on siliceous bedrock were dominated by Carex nigra, while $C$. rostrata was the main vegetation on the calcareous bedrock (Table 1). Fens with an area ranging from 10 to $800 \mathrm{~m}^{2}$ were chosen, with the exception of the Oberaar fen one, which covers an area of $3,000 \mathrm{~m}^{2}$. There was one study site per fen and these study sites were characterized as nutrient-poor to mesotrophic (Rydin and Jeglum 2006). Most of the study sites were sampled once, in either 2010 or 2011, between July and August (Table 2). However, two sites (GA and OA1) were sampled twice, once in 2010 and once in 2011. The microbiological structures of the fens at Oberaar and Göschener Alp have been described by Franchini and Zeyer (2012) and by Liebner et al. (2012), respectively.

Quantification of methane emissions

Methane emissions into the atmosphere were measured between noon and 3.00 p.m. using static transparent chambers $(30 \times 30 \times 30 \mathrm{~cm}$, volume of 


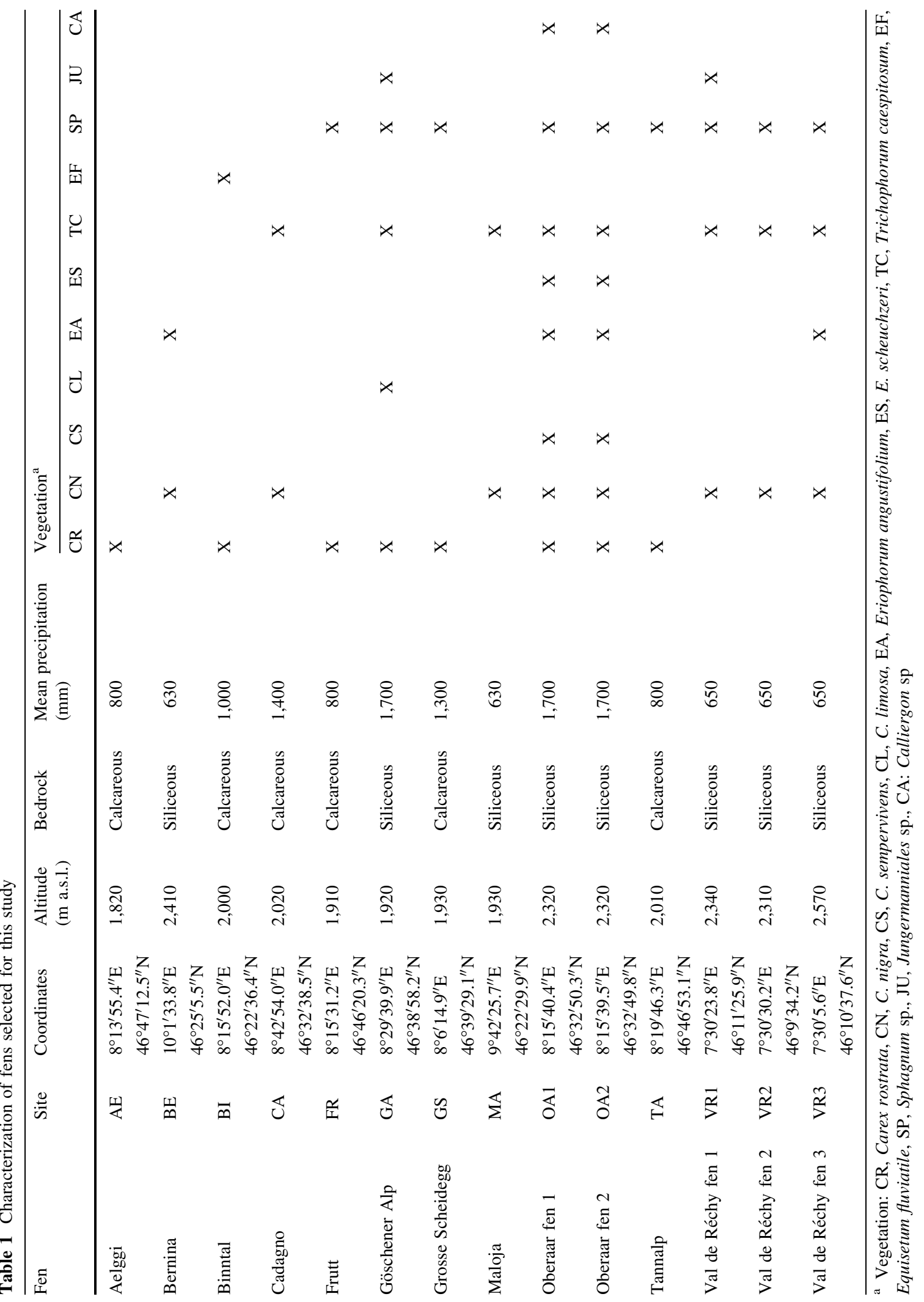




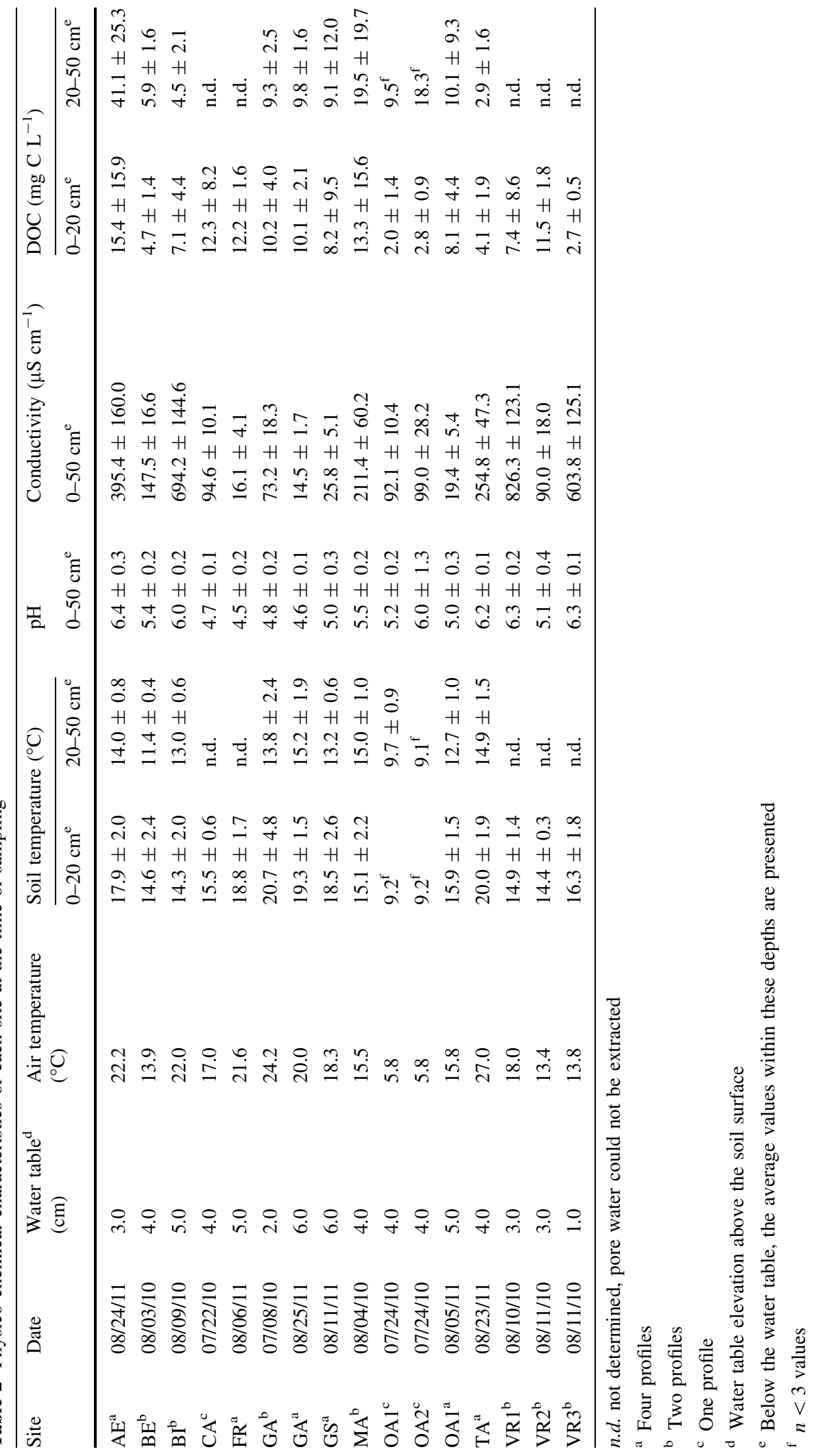


$0.027 \mathrm{~m}^{3}$ ), as described in Liebner et al. (2012). At each site, four chambers were gently placed into standing water within a radius of $5 \mathrm{~m}$. Sampling was performed using portable walkways to minimize disturbance. For each chamber, the average height between the water table elevation and the top of the chamber was measured and the volume of the headspace was recorded. After several minutes of equilibration, the openings on the top of the chamber were carefully closed with butyl rubber stoppers. A needle connected to a $50 \mathrm{~mL}$ syringe was inserted through a stopper. The chambers were not equipped with fans and therefore the piston of the syringe was pulled and pushed five times to mix the gas in the chamber. Immediately after mixing, a $50 \mathrm{~mL}$ gas sample was taken and injected into a $20 \mathrm{~mL}$ glass vial, which had been previously flushed with $\mathrm{N}_{2}$ and evacuated. This procedure was repeated every $5 \mathrm{~min}$ up to $30 \mathrm{~min}$ (seven samples in total).

Concentrations of $\mathrm{CH}_{4}$ were measured by gas chromatography (Trace GC Ultra; Thermo Electron Corporation, Rodano, Italy) using a $2 \mathrm{~m}$ Porapak N $100 / 120$ mesh column (1/16" outer diameter and $1 \mathrm{~mm}$ inner diameter) and a flame ionization detector (FID). The column and detector temperatures were set at 30 and $250{ }^{\circ} \mathrm{C}$, respectively. The carrier gas $\left(\mathrm{N}_{2}\right)$ flow velocity was $30 \mathrm{~mL} \mathrm{~min}^{-1}(30 \mathrm{kPa})$; the FID hydrogen was set at $35 \mathrm{kPa}$ and the synthetic air flow at $350 \mathrm{kPa}$. Peak areas calibration was performed with Messer CAN-Gas standards $\left(\mathrm{CH}_{4}\right.$ in synthetic air 5.0, Messer Schweiz AG, Lenzburg, Switzerland) over a concentration range from 1 to $5,000 \mathrm{ppm}$ and integrated using the software Chromeleon (Vers. 6.8, Dionex AG, Olten, Switzerland).

The emission of $\mathrm{CH}_{4}$ into the atmosphere was calculated from the $\mathrm{CH}_{4}$ accumulated in the chamber over 30 min using linear regression (van der Nat and Middelburg 1998; Ding et al. 2005; Liebner et al. 2012). Linear regression with $r^{2}<0.95$ was omitted from further analyses. The increase in $\mathrm{CH}_{4}$ concentrations was linear and no ebullition was observed in our measurements.

\section{Plant species and biomass}

After each emission measurement the plant biomass covered by the chamber was harvested by clipping the plants at the water table with scissors. The plant material was wrapped in aluminum foil and taken to the laboratory. Dead biomass (i.e. brown and black residues of stems and leaves) was discarded and the remaining live biomass (i.e. green stems and leaves) was dried at $70{ }^{\circ} \mathrm{C}$ for $48 \mathrm{~h}$ and weighed. Throughout this report the term "plant biomass" refers exclusively to the dry weight (units: $\mathrm{g} \mathrm{m}^{-2}$ ) of live plant biomass above the water table. The plant species reported in Table 2 made up more than $95 \%$ of the live biomass for each emission measurement.

Pore water sampling and physico-chemical characteristics

Pore water was sampled to obtain a profile of DOC and $\mathrm{CH}_{4}$ pore water concentrations to a depth of $50 \mathrm{~cm}$. The pore water was extracted along the profile using brass tubes. These tubes $(0.3 \mathrm{~cm}$ inner diameter $)$ were closed at one end and perforated with $0.1 \mathrm{~cm}$ diameter closely spaced holes for the first $1 \mathrm{~cm}$ from the closed end. The perforations allow the extraction of pore water and avoid the co-extraction of peat material. Nevertheless, at some sites sampling was not possible below certain depths as the peat material caused severe clogging of the brass tubes.

A series of brass tubes were inserted vertically into the water/soil to allow extraction of the pore water profile at the following depths below the water table: 1.0 (considered to reflect the surface water conditions), 2.5, 5.0, 7.5, 10.0, 15.0, 20.0, 30.0, 40.0 and $50.0 \mathrm{~cm}$. Each tube was connected to a threeway valve (Discofix C-3, Braun Melsungen AG, Melsungen, Germany) by silicon tubing. Seven $\mathrm{mL}$ of pore water (equivalent to the dead volume of the tube) was pulled through the tube with a $10 \mathrm{~mL}$ syringe. The valve was subsequently closed to hold the pore water inside and to exclude oxygen contaminations from the atmosphere. After $1 \mathrm{~h}$ of equilibration, $7 \mathrm{~mL}$ of pore water was extracted and discarded.

For DOC measurements, $20 \mathrm{~mL}$ of pore water was collected from each depth and immediately filtered onsite through $0.45 \mu \mathrm{m}$ nylon filters (Wicom Perfect Flow, Meienfeld, Switzerland). Before sampling, the filters were washed with $10 \mathrm{~mL}$ of distilled water to remove contaminants. Each filtered sample was acidified with $0.1 \mathrm{~mL}$ of a $1 \mathrm{M} \mathrm{HCl}$ solution (King et al. 1998) and later stored in a glass vial at $-20^{\circ} \mathrm{C}$. DOC analysis was performed with a Shimadzu TOC-5000 analyzer (Shimadzu SSI, Columbia, MD). 
To determine the concentration of dissolved $\mathrm{CH}_{4}$ in pore water along the profile, $5 \mathrm{~mL}$ of pore water was collected with a $10 \mathrm{~mL}$ plastic syringe as described above and immediately injected into to previously $\mathrm{N}_{2-}$ flushed vials containing $0.1 \mathrm{~mL}$ of a $1 \mathrm{M} \mathrm{HCl}$ solution (Frenzel and Karofeld 2000; Joabsson and Christensen 2001). The vials were stored at $4{ }^{\circ} \mathrm{C}$ until analysis. Methane concentrations in the vial headspace were measured by gas chromatography, and concentrations of dissolved $\mathrm{CH}_{4}$ were subsequently calculated using the headspace method according to Liebner et al. (2012). At each site in 2010, one or two independent profiles of $\mathrm{CH}_{4}$ pore water concentrations were measured. However, for the sites sampled in 2011, four independent profiles were measured.

Similarly, depth profiles of conductivity and $\mathrm{pH}$ were analyzed in situ according to Liebner et al. (2012) using a Multi 350i probe (WTW, Laboratory and Field Products, Nova Analytics, Woburn, MA) connected to a LR 325/01 conductivity cell and a SenTix $51 \mathrm{pH}$ electrode. Prior to using the LR 325/01 conductivity cell, its response was tested using $\mathrm{KCl}$ solutions. This test demonstrated that up to $1,200 \mu \mathrm{S} \mathrm{cm}^{-1}$ the signal is a linear function of the $\mathrm{KCl}$ concentration.

Oxygen and temperature measurements along the profile

Oxygen pore water concentrations along the profiles were measured in situ with a Fibox 3-trace v3 planar trace oxygen minisensor (PreSens, Regensburg, Germany), as previously reported (Liebner et al. 2012). Temperature and oxygen pore water concentrations were logged after an equilibration time of about $15 \mathrm{~min}$ at the same depths as for DOC and $\mathrm{CH}_{4}$. However, at some sites oxygen pore water concentrations were determined colorimetrically using a DRr890 colorimeter (HACH Lange, Rheineck, Switzerland) with high and low range AccuVac Dissolved Oxygen Reagent Ampules (HACH Lange). $25 \mathrm{~mL}$ of pore water was extracted from the brass tubes as previously described. Approximately $5 \mathrm{~mL}$ was slowly discarded to avoid exposure of the water samples to air, and $20 \mathrm{~mL}$ was transferred immediately to the AccuVac glass ampules and measured using the DRr890 colorimeter (HACH Lange).

The colorimetric method was used at sites BI, MA, VR1, VR2 and VR3, whereas the oxygen minisensor method was used at all other sites. Both methods have been applied in environmental studies (e.g. Kleikemper et al. 2005; Liebner et al. 2012); however, each method also has limitations: The minisensor method is temperature dependent and requires long equilibration times. Moreover, in peat soil the measuring device can clog. On the other hand, the colorimetric method requires large volumes of pore water, and the samples can be exposed to air prior to measurement. Preliminary tests comparing the two methods showed deviations in the range of 2-25\% from each other. This is in agreement with data reported by Bagshaw et al. (2011), who also compared different methods.

\section{Statistical analysis}

The statistical analysis was performed with the software R (version 2.15.2) (R Development Core Team 2012). Methane emissions, plant biomass, $\mathrm{CH}_{4}$, oxygen and DOC pore water concentrations, as well as data for conductivity were logarithmically transformed to approximate normal distributions. Normality of the data was tested using the Shapiro-Wilk test. Differences between bedrock or vegetation type, and $\mathrm{CH}_{4}$ emissions, plant biomass and physico-chemical parameters (e.g. soil and air temperature, DOC pore water concentrations) were identified with two-sample $t$-tests.

Linear mixed models were used to perform stepwise multiple linear regression analyses. First, the relationship between $\mathrm{CH}_{4}$ emissions (dependent variable) and the following fixed parameters were evaluated: altitude, bedrock and vegetation type, plant biomass, air temperature and pressure, precipitation, and the mean values (depth 0-20 cm) of conductivity, $\mathrm{pH}$, soil temperature, and $\mathrm{CH}_{4}$, oxygen and DOC pore water concentration. Second, the relationships between $\mathrm{CH}_{4}$ pore water concentration $(0-20 \mathrm{~cm}$, dependent variable) and the following fixed parameters were evaluated: altitude, bedrock and vegetation type, plant biomass, air temperature and pressure, precipitation, conductivity, $\mathrm{pH}$, soil temperature, and oxygen and DOC pore water concentration. These linear mixed models were implemented using $\mathrm{R}$ package "lme4" (function "lmer") (Bates et al. 2011). The sites were included as a random effect to account for the variability observed between sites. Normality and homogeneity were examined by visually inspecting plots of the residuals against fitted 
values. Selection of the best-fitting models was performed based upon Akaike Information Criterion (AIC) values, and calculated with the Restricted Maximum Likelihood (REML) (Johnson and Omland 2004). Thus, the simplest method that performed the best was applied. In addition, to assess the validity of the mixed parameter analyses, ANOVA analyses were performed comparing the models with fixed parameters to the null models with only the random effect. Results in which the model including fixed effects did not differ significantly from the null models were rejected. The significance level for all tests was $P=0.05$. Pore water below $20 \mathrm{~cm}$ was not included in this analysis because of difficulty sampling below this depth.

\section{Results}

Physico-chemical characteristics of the fen pore water

Physico-chemical characteristics are summarized in Table 2. At all sites the water table elevation varied from 1 to $6 \mathrm{~cm}$ above the soil surface. From 0 to $20 \mathrm{~cm}$, soil temperatures differed substantially between the study sites (9.2 to $20.7 \pm 4.8^{\circ} \mathrm{C}$, Table 2). These temperatures partially reflected the air temperatures at the time of sampling. In deeper soil layers the temperatures of the different sites were more equal $\left(9.1\right.$ to $\left.15.2 \pm 1.9^{\circ} \mathrm{C}\right)$.

The $\mathrm{pH}$ values of pore water ranged from slightly acidic (max. $\mathrm{pH} 6.4 \pm 0.3$ ) to acidic (min. $\mathrm{pH}$ $4.5 \pm 0.2$ ), and conductivities ranged broadly from $14.5 \pm 1.7$ to $826.3 \pm 123.1 \mu \mathrm{S} \mathrm{cm}^{-1}$. DOC pore water concentrations varied from $2.0 \pm 1.4$ to $15.4 \pm 15.9 \mathrm{mg} \mathrm{C} \mathrm{L}^{-1}$ for the first $20 \mathrm{~cm}$ and from $2.9 \pm 1.6$ to $41.1 \pm 25.3 \mathrm{mg} \mathrm{C} \mathrm{L}^{-1}$ in deeper soil layers. No significant difference in water table elevation between sites located on siliceous and those on calcareous bedrocks was detected $(P=0.314)$. Parameters, such as $\mathrm{pH}(P=0.982)$, conductivity $(P=0.872)$, DOC pore water concentrations from 0 to $20 \mathrm{~cm}(P=0.477)$ and 20 to $50 \mathrm{~cm}(P=0.763)$, and soil temperatures from 0 to $20 \mathrm{~cm}(P=0.148)$ and 20 to $50 \mathrm{~cm}(P=0.853)$ did not vary significantly. Mean altitudes were $2,257 \pm 243 \mathrm{~m}$ a.s.l. and $1,948 \pm 77 \mathrm{~m}$ a.s.l. for fen sites located on siliceous and calcareous bedrock, respectively.
Plant species and plant biomass

C. nigra and $C$. rostrata dominated the vegetation at the study sites. Sites on siliceous bedrock were dominated by $C$. nigra, while calcareous sites were dominated by $C$. rostrata (Table 1 ). This difference was not significant $(P=0.094)$. The average plant biomass for $C$. nigra ranged from $44.4 \pm 33.5$ to $101.7 \pm 15.8 \mathrm{~g} \mathrm{~m}^{-2}$ and for $C$. rostrata from $67.0 \pm 17.8$ to $430.1 \pm 361.0 \mathrm{~g} \mathrm{~m}^{-2}$ (Table 3). $C$. rostrata biomass was significantly higher than $C$. nigra biomass $(P=0.001)$. Moreover, plant biomass on siliceous bedrock was lower than on calcareous bedrock $(P=0.002)$.

Methane emissions

Methane emissions ranged from $74 \pm 43 \mathrm{mg} \mathrm{CH}_{4}$ $\mathrm{m}^{-2}$ day $^{-1}$ at VR3 to $711 \pm 212 \mathrm{mg} \mathrm{CH}_{4} \mathrm{~m}^{-2}$ day $^{-1}$ at BI during the 2010 campaign, and from $153 \pm 31 \mathrm{mg} \quad \mathrm{CH}_{4} \quad \mathrm{~m}^{-2}$ day $^{-1}$ at GA to $539 \pm 58 \mathrm{mg} \mathrm{CH}_{4} \mathrm{~m}^{-2}$ day $^{-1}$ at TA during 2011 (Table 2). At the sites that were sampled twice, GA and $\mathrm{OA} 1, \mathrm{CH}_{4}$ emissions in 2011 were roughly $25 \%$ lower than emissions in 2010 (Table 2), however, the emissions were not significantly different $(P=0.122$; $P=0.217$, respectively). An average $\mathrm{CH}_{4}$ emission of $162 \pm 76(74 \pm 43$ to $246 \pm 45) \mathrm{mg} \mathrm{CH}_{4} \mathrm{~m}^{-2}$ day $^{-1}$ was observed at siliceous sites, while the average emission at calcareous sites was $503 \pm 176$ $(328 \pm 120$ to $711 \pm 212) \mathrm{mg} \mathrm{CH}_{4} \mathrm{~m}^{-2} \mathrm{day}^{-1}$. In addition, an average $\mathrm{CH}_{4}$ emission of $232 \pm 190$ $(74 \pm 43$ to $544 \pm 147) \mathrm{mg} \mathrm{CH}_{4} \mathrm{~m}^{-2}$ day $^{-1}$ was measured at sites covered by $C$. nigra, whereas the average emission at $C$. rostrata sites was $398 \pm 218$ $(153 \pm 31$ to $711 \pm 212) \mathrm{mg} \mathrm{CH}_{4} \mathrm{~m}^{-2}$ day $^{-1}$. Significant differences were found between bedrock types and $\mathrm{CH}_{4}$ emissions $(P<0.001)$ and between vegetation types and $\mathrm{CH}_{4}$ emissions $(P=0.005)$.

Methane and oxygen pore water concentrations

Methane pore water concentrations were determined along a profile from the water table down to $50 \mathrm{~cm}$, where extraction to this depth was possible. At all sites (except CA and OA2), in the first few $\mathrm{cm}$ below the water table, $\mathrm{CH}_{4}$ pore water concentrations were low but they steadily increased down to $20 \mathrm{~cm}$ (27 \pm $34-273 \pm 236 \mu \mathrm{M})$. From 20 to $50 \mathrm{~cm}, \mathrm{CH}_{4}$ pore 
Table 3 Methane emissions and plant biomass at the different study sites
Mean values $(n=4)$ with standard deviations are presented

n.d. plant biomass not determined

a See Table 1 footnotes

\begin{tabular}{lllll}
\hline Site & Date & Vegetation $^{\mathrm{a}}$ & $\begin{array}{l}\text { Methane emissions } \\
\left(\mathrm{mg} \mathrm{CH}_{4} \mathrm{~m}^{-2} \mathrm{day}^{-1}\right)\end{array}$ & $\begin{array}{l}\text { Plant biomass } \\
\left(\mathrm{g} \mathrm{m}^{-2}\right)\end{array}$ \\
\hline $\mathrm{AE}$ & $08 / 24 / 11$ & $\mathrm{CR}$ & $462 \pm 178$ & $430.1 \pm 361.0$ \\
$\mathrm{BE}$ & $08 / 03 / 10$ & $\mathrm{CN}, \mathrm{EA}$ & $219 \pm 54$ & $70.9 \pm 8.9$ \\
$\mathrm{BI}$ & $08 / 09 / 10$ & $\mathrm{CR}$ & $711 \pm 212$ & $244.8 \pm 131.0$ \\
$\mathrm{CA}$ & $07 / 22 / 10$ & $\mathrm{CN}$ & $544 \pm 147$ & $58.1 \pm 9.3$ \\
$\mathrm{FR}$ & $08 / 06 / 11$ & $\mathrm{CR}$ & $328 \pm 120$ & $141.7 \pm 32.8$ \\
$\mathrm{GA}$ & $07 / 08 / 10$ & $\mathrm{CR}$ & $206 \pm 48$ & n.d. \\
$\mathrm{GA}$ & $08 / 25 / 11$ & $\mathrm{CR}$ & $153 \pm 31$ & $67.0 \pm 17.8$ \\
$\mathrm{GS}$ & $08 / 11 / 11$ & $\mathrm{CR}$ & $421 \pm 95$ & $153.6 \pm 71.2$ \\
$\mathrm{MA}$ & $08 / 04 / 10$ & $\mathrm{CN}$ & $213 \pm 76$ & $65.0+14.1$ \\
OA1 & $07 / 24 / 10$ & $\mathrm{CR}$ & $225 \pm 19$ & n.d. \\
OA2 & $07 / 24 / 10$ & $\mathrm{EA}$ & $246 \pm 45$ & n.d. \\
OA1 & $08 / 05 / 11$ & $\mathrm{CR}$ & $172 \pm 69$ & $78.8 \pm 23.5$ \\
TA & $08 / 23 / 11$ & $\mathrm{CR}$ & $539 \pm 58$ & $205.8 \pm 17.4$ \\
VR1 & $08 / 10 / 10$ & $\mathrm{CN}, \mathrm{SP}$ & $104 \pm 55$ & $44.4 \pm 33.5$ \\
VR2 & $08 / 11 / 10$ & $\mathrm{CN}$ & $144 \pm 76$ & $70.6 \pm 27.8$ \\
VR3 & $08 / 11 / 10$ & $\mathrm{CN}$ & $74 \pm 43$ & \\
\hline
\end{tabular}

water concentrations remained high $(64 \pm 71-627 \pm$ $555 \mu \mathrm{M})$ (Table 4). High $\mathrm{CH}_{4}$ pore water concentrations $(>250 \mu \mathrm{M})$ were detected near the surface of the water table at $\mathrm{CA}$ and $\mathrm{OA} 2$, but at these sites pore water could not be extracted below $25 \mathrm{~cm}$ due to clogging. Furthermore, at CA, gas bubbles (50\% of the total volume extracted) were present in pore water samples extracted from 15 to $20 \mathrm{~cm}$, resulting in high $\mathrm{CH}_{4}$ pore water concentrations (Table 4). At several sites, pore water could not be extracted below $15-25 \mathrm{~cm}$ (12 profiles) or $30-40 \mathrm{~cm}$ (five profiles) (Table 4 , footnotes). No significant differences were found between $\mathrm{CH}_{4}$ pore water concentrations from 0 to $20 \mathrm{~cm}$ and bedrock types $(P=0.294)$ or vegetation types $(P=0.143)$. Similarly, $\mathrm{CH}_{4}$ pore water concentrations at a depths $20-50 \mathrm{~cm}$ were not significantly different between bedrock types $(P=0.993)$ or vegetation types $(P=0.347)$.

Oxygen pore water concentrations generally decreased to zero within the first $20 \mathrm{~cm}$ below the water table (Table 4). At most sites, average oxygen pore water concentrations from 0 to $20 \mathrm{~cm}$ were above $5.0 \pm 4.8 \mu \mathrm{M}$. Oxygen pore water concentrations were significantly different between vegetation types $(P=0.026)$. Higher oxygen pore water concentrations were observed with $C$. rostrata $(75.9 \pm 51.4 \mu \mathrm{M})$ than C. nigra $(24.3 \pm 19.0 \mu \mathrm{M})$. From 20 to $50 \mathrm{~cm}$ average oxygen pore water concentrations were lower than $6.6 \pm 9.6 \mu \mathrm{M}$ (Table 4) at most sites.

Methane and oxygen pore water concentration profiles

Some of the concentrations presented in Table 4 are based on one or two profiles or pore water samples could not be extracted below 15 or $30 \mathrm{~cm}$ (Table 4, footnotes) and thus this data is not presented in Fig. 2. However, at four sites sampled in 2011 (GA, GS, OA1 and TA), four independent profiles to a depth of $50 \mathrm{~cm}$ were measured. For these four profiles the mean values of $\mathrm{CH}_{4}$ and oxygen pore water concentrations at each depth are shown in Fig. 2. At GA in $2011, \mathrm{CH}_{4}$ pore water concentrations were generally low $(<100 \mu \mathrm{M})$ and $\mathrm{CH}_{4}$ pore water concentrations increased with depth (Fig. 2a). The profiles obtained at GS and TA in 2011 were quite similar to each other. The profiles were characterized by an exponential increase of $\mathrm{CH}_{4}$ pore water concentrations from 0 to $7.5 \mathrm{~cm}$, followed by an almost linear increase from 7.5 to 15 or $20 \mathrm{~cm}$, where the highest $\mathrm{CH}_{4}$ pore water concentrations were observed (Fig. 2a). Below 15-20 $\mathrm{cm} \mathrm{CH}_{4}$ pore water concentrations decreased again (Fig. 2a).

At GA in 2011, high oxygen pore water concentrations could be detected down to $30 \mathrm{~cm}$ (Fig. 2b). At 
Table 4 Mean $\mathrm{CH}_{4}$ and oxygen pore water concentrations at two different depth intervals (0-20 cm and 20-50 cm)

\begin{tabular}{|c|c|c|c|c|c|}
\hline \multirow[t]{2}{*}{ Site } & \multirow[t]{2}{*}{ Date } & \multicolumn{2}{|l|}{ Methane $(\mu \mathrm{M})$} & \multicolumn{2}{|l|}{ Oxygen $(\mu \mathrm{M})$} \\
\hline & & $0-20 \mathrm{~cm}^{\mathrm{d}}$ & $20-50 \mathrm{~cm}^{\mathrm{d}}$ & $0-20 \mathrm{~cm}^{\mathrm{d}}$ & $20-50 \mathrm{~cm}^{\mathrm{d}}$ \\
\hline $\mathrm{AE}^{\mathrm{a}}$ & $08 / 24 / 11$ & $92 \pm 63$ & $153 \pm 37^{\mathrm{g}}$ & $83.2 \pm 64.0$ & $0.0 \pm 0.0^{\mathrm{g}}$ \\
\hline $\mathrm{BE}^{\mathrm{b}}$ & 08/03/10 & $273 \pm 236$ & $627 \pm 555$ & $31.6 \pm 64.5$ & $0.7 \pm 1.2$ \\
\hline $\mathrm{BI}^{\mathrm{b}}$ & 08/09/10 & $244 \pm 111$ & $323 \pm 47$ & $5.2 \pm 5.7$ & $1.2 \pm 1.7$ \\
\hline $\mathrm{CA}^{\mathrm{c}}$ & $07 / 22 / 10$ & $955 \pm 1124^{\mathrm{e}, \mathrm{f}}$ & n.d. & $5.0 \pm 4.8^{\mathrm{e}}$ & n.a. \\
\hline $\mathrm{FR}^{\mathrm{a}}$ & 08/06/11 & $56 \pm 90^{\mathrm{e}}$ & n.d. & $102.6 \pm 91.6^{\mathrm{e}}$ & n.a. \\
\hline $\mathrm{GA}^{\mathrm{b}}$ & 07/08/10 & $192 \pm 132$ & $178 \pm 71^{\mathrm{g}}$ & $0.0 \pm 0.0$ & $0.0 \pm 0.0^{\mathrm{g}}$ \\
\hline $\mathrm{GA}^{\mathrm{a}}$ & $08 / 25 / 11$ & $28 \pm 53$ & $64 \pm 71$ & $165.0 \pm 58.3$ & $39.4 \pm 56.4$ \\
\hline $\mathrm{GS}^{\mathrm{a}}$ & $08 / 11 / 11$ & $116 \pm 153$ & $255 \pm 79$ & $74.0 \pm 61.6$ & $0.0 \pm 0.0$ \\
\hline $\mathrm{MA}^{\mathrm{b}}$ & 08/04/10 & $191 \pm 145$ & $154 \pm 86$ & $58.0 \pm 87.7$ & $0.8 \pm 1.5$ \\
\hline $\mathrm{OA} 1^{\mathrm{c}}$ & $07 / 24 / 10$ & $202 \pm 93$ & $174 \pm 21^{\mathrm{g}}$ & n.a. & n.a. \\
\hline $\mathrm{OA} 2^{\mathrm{c}}$ & $07 / 24 / 10$ & $273 \pm 57^{\mathrm{e}}$ & n.d. & n.a. & n.a. \\
\hline $\mathrm{OA} 1^{\mathrm{a}}$ & 08/05/11 & $67 \pm 70$ & $130 \pm 31$ & $71.9 \pm 111.4$ & $6.6 \pm 9.6$ \\
\hline $\mathrm{TA}^{\mathrm{a}}$ & $08 / 23 / 11$ & $114 \pm 120$ & $249 \pm 36$ & $29.4 \pm 33.4$ & $0.0 \pm 0.0$ \\
\hline $\mathrm{VR} 1^{\mathrm{b}}$ & 08/10/10 & $34 \pm 68^{\mathrm{e}}$ & n.d. & $19.1 \pm 22.6^{\mathrm{e}}$ & n.a. \\
\hline $\mathrm{VR} 2^{\mathrm{b}}$ & $08 / 11 / 10$ & $27 \pm 34^{\mathrm{e}}$ & n.d. & $9.5 \pm 15.4^{\mathrm{e}}$ & n.a. \\
\hline $\mathrm{VR} 3^{\mathrm{b}}$ & $08 / 11 / 10$ & $43 \pm 51^{\mathrm{e}}$ & n.d. & $22.4 \pm 42.5^{\mathrm{e}}$ & n.a. \\
\hline
\end{tabular}

Mean values with standard deviations are presented

n.d. not determined, pore water could not be extracted, n.a. not analyzed

${ }^{\text {a }}$ Four profiles

b Two profiles

c One profile

d Below the water table

e Pore water extraction was not possible below $15-25 \mathrm{~cm}$

${ }^{\mathrm{f}}$ Gas bubbles were co-extracted with pore water

g Pore water extraction was not possible below $30-40 \mathrm{~cm}$

GS, OA1 and TA oxygen pore water concentration profiles displayed a similar trend with concentrations close to zero from 7.5 to $15 \mathrm{~cm}$ (Fig. 2b).

Factors related to methane dynamics

Statistical analyses revealed that the $\mathrm{CH}_{4}$ emissions were positively related to plant biomass and average $\mathrm{CH}_{4}$ pore water concentrations from 0 to $20 \mathrm{~cm}$ (Table 5; Equation 1). Moreover, $\mathrm{CH}_{4}$ emissions were lower on siliceous bedrock than on calcareous bedrock. Other environmental factors, such as altitude, vegetation type, $\mathrm{pH}$ and oxygen pore water concentration had no direct influence on $\mathrm{CH}_{4}$ emissions at the studied sites.

In addition, $\mathrm{CH}_{4}$ pore water concentrations from 0 to $20 \mathrm{~cm}$ were negatively related to oxygen pore water concentrations (Table 5; Equation 2), while other environmental factors had no direct influence on $\mathrm{CH}_{4}$ pore water concentrations at shallow depths.

\section{Discussion}

Plant-mediated transport of methane from alpine fens

An almost linear increase of $\mathrm{CH}_{4}$ pore water concentrations from 7.5 to $15 \mathrm{~cm}$ at GS and TA, and from 5 to $10 \mathrm{~cm}$ at OA1 was observed in 2011 (Fig. 2); therefore, the upward $\mathrm{CH}_{4}$ flux in pore water using Fick's first law of diffusion was calculated similarly to Beer and Blodau (2007) and Hornibrook et al. (2009). The diffusion coefficient of $\mathrm{CH}_{4}$ in water $\left(\mathrm{D}_{\mathrm{w}}\right.$, methane $)$ was determined from the mean temperature measured in situ across the depth interval of the linear regression 
Fig. 2 Methane (a) and oxygen (b) pore water concentration profiles from four fens located in the Swiss Alps. Bars denote standard deviations of the means $(n=4)$ (a) $\mathrm{CH}_{4}[\mu \mathrm{M}]$

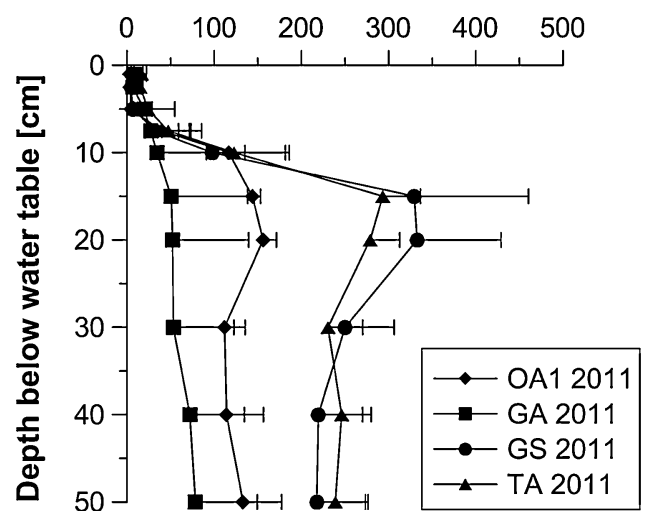

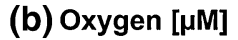

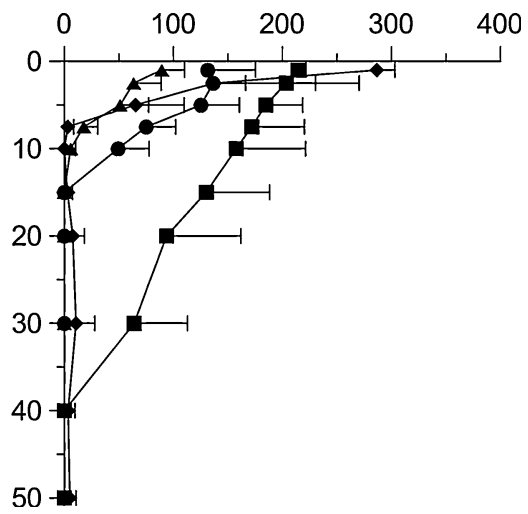

Table 5 Linear mixed models for $\mathrm{CH}_{4}$ emissions $(n=37)$ and for $\mathrm{CH}_{4}$ pore water concentrations (depths $\left.0-20 \mathrm{~cm}, n=160\right)$

\begin{tabular}{|c|c|c|c|c|}
\hline Equation & Dependent variable & Linear mixed model & AIC & $P$ value \\
\hline 1 & Methane emissions & $\log [\mathrm{emi}]=1.849+0.265 \cdot \log [\mathrm{pla}]+0.110 \cdot \log [\operatorname{met} 20]-0.347 \cdot$ bed & -12.5 & $<0.001$ \\
\hline 2 & $\begin{array}{l}\text { Methane pore water } \\
\text { concentrations } \\
0-20 \mathrm{~cm}\end{array}$ & $\log [\mathrm{met}]=2.386-0.629 \cdot \log [\mathrm{oxy}]$ & 293.4 & $<0.001$ \\
\hline
\end{tabular}

Emi $\mathrm{CH}_{4}$ emissions, Pla plant biomass, Met20 $\mathrm{CH}_{4}$ pore water concentration (mean value 0-20 $\left.\mathrm{cm}\right)$, Bed bedrock (calcareous $=0$, siliceous = 1), Met $\mathrm{CH}_{4}$ pore water concentration 0-20 cm, Oxy oxygen pore water concentration 0-20 cm

using the polynomial regression for $\mathrm{D}_{\mathrm{w}}$, methane in water (83rd Edition of the Handbook of Physics and Chemistry). The diffusion coefficient of $\mathrm{CH}_{4}$ in soil $\left(\mathrm{D}_{\mathrm{s}}\right.$, methane) was calculated using the equation (Lerman 1979):

$\mathrm{D}_{\mathrm{s}}=\mathrm{D}_{\mathrm{w}} \varphi^{2}$

where $\varphi$ stands for porosity which was assumed to be 0.9 at shallow soil depths according to Letts et al. (2000). The calculated diffusive $\mathrm{CH}_{4}$ fluxes were 4 (OA1), 7 (GS) and $6 \mathrm{mg} \mathrm{CH}_{4} \mathrm{~m}^{-2}$ day $^{-1}$ (TA), which accounts only for $2.3,1.7$ and $1.1 \%$, respectively, of the total $\mathrm{CH}_{4}$ emissions into the atmosphere. These emissions are in the same range of previously reported values from a Swiss alpine fen (Liebner et al. 2012). The results suggest that the $\mathrm{CH}_{4}$ transport through the aerenchyma of $C$. rostrata is the major emission pathway in the alpine fens analyzed. Similar results have been reported from other wetlands by measuring $\mathrm{CH}_{4}$ emissions in the presence and absence of plants (Whiting and Chanton 1992; Waddington et al. 1996; King et al. 1998).

Within the first $5-7.5 \mathrm{~cm}$ below the water table at GS and TA and $2.5-5 \mathrm{~cm}$ at $\mathrm{OA} 1$, the $\mathrm{CH}_{4}$ pore water concentration curves have a concave shape (Fig. 2a). However, at GS and OA1 for this depth interval there was free water above the soil surface, where the governing transport mechanisms for $\mathrm{CH}_{4}$ remain unknown. Therefore, these sections of the $\mathrm{CH}_{4}$ pore water concentration profiles were not considered for further analyses. The concavity of the profiles at TA from 5 to $7.5 \mathrm{~cm}$, suggested that the shallow layers are a sink for $\mathrm{CH}_{4}$. The $\mathrm{CH}_{4}$ sink or consumption was determined by calculating the difference between upward fluxes at depths from 5 to $7.5 \mathrm{~cm}$ and from 7.5 to $15 \mathrm{~cm}$ (Fechner and Hemond 1992). A sink of $4 \mathrm{mg}$ $\mathrm{CH}_{4} \mathrm{~m}^{-2}$ day $^{-1}$ accounts for about $67 \%$ of the diffusive flux calculated from 7.5 to $15 \mathrm{~cm}$ depth, and might be the result of $\mathrm{CH}_{4}$ consumption by methanotrophic bacteria. However, we are aware that $\mathrm{CH}_{4}$ pore water concentration profiles may be subjected to spatial and temporal variability. While several studies have determined emissions to the atmosphere, these calculations aim to quantify the subsurface processes. The obtained results complement previous findings by Fechner and Hemond (1992) and Hornibrook et al. (2009).

In addition to diffusion and plant mediated transport, ebullition, has been reported to be an important 
process in fens (Whalen 2005). However, ebullition was not detected during $\mathrm{CH}_{4}$ flux measurements at our field sites, which is in agreement with a recent study quantifying the episodic ebullition to approximately $3 \%$ of the total $\mathrm{CH}_{4}$ emission (Green and Baird 2013).

Environmental factors related to methane dynamics

Methane emissions (74 \pm 43 to $711 \pm 212 \mathrm{mg} \mathrm{CH}$ $\mathrm{m}^{-2}$ day $^{-1}$ ) reported in this study showed high variability within and between the sites. High variability in $\mathrm{CH}_{4}$ emissions has been reported in most studies where static chamber techniques have been used to quantify gas-exchanges from the subsurface to the atmosphere. Bubier et al. (1993) reported a withinsite variability of $\mathrm{CH}_{4}$ emissions ranging from 86 to $200 \%$ that could be explained mainly by differences in the site microtopography. Methane emissions in our study are in the same range as those in the arctic tundra (Bartlett et al. 1992; Whalen and Reeburgh 1992).

A relationship between $\mathrm{CH}_{4}$ emissions and bedrock type was found in the present study (Table 5, Equation 1). On siliceous bedrock, $\mathrm{CH}_{4}$ emissions ranged from $74 \pm 43$ to $246 \pm 45 \mathrm{mg} \mathrm{CH}_{4} \mathrm{~m}^{-2}$ day $^{-1}$. These emissions are in agreement with data reported by Koch et al. (2007) and Liebner et al. (2012), who also investigated fens on siliceous bedrock. On calcareous bedrock, $\mathrm{CH}_{4}$ emissions ranged from $328 \pm 120$ to $711 \pm 212 \mathrm{mg} \mathrm{CH}_{4} \mathrm{~m}^{-2}$ day $^{-1}$; however, these sites were also located at lower altitudes and plant biomass was higher. Moreover, no significant differences in physico-chemical parameters were found between sites located on siliceous and calcareous bedrock. This supports Chapman et al. (2003) who suggested that the water chemistry of fens is controlled by biologically-mediated processes rather than by water sources.

A positive correlation was found between $\mathrm{CH}_{4}$ emissions and vascular plant biomass (Table 5, Equation 1), which is consistent with results reported from fens located in the northern hemisphere (Bellisario et al. 1999; Joabsson and Christensen 2001; von Fischer et al. 2010) and in alpine regions (Koch et al. 2007; Chen et al. 2011). Moreover, in most cases $C$. rostrata had higher plant biomass than $C$. nigra, which is in full agreement with data published by Visser et al. (2000). This may have an indirect influence on the $\mathrm{CH}_{4}$ emissions.
A positive correlation was found between $\mathrm{CH}_{4}$ emissions and $\mathrm{CH}_{4}$ pore water concentrations at shallow depths (Table 5, Equation 1). In addition, $\mathrm{CH}_{4}$ pore water concentrations were negatively related to oxygen pore water concentrations at the same depth (Table 5, Equation 2). Further, the aerenchyma of vascular plants allows for the diffusion of oxygen from the atmosphere down to the rhizosphere, where it stimulates the activity of methanotrophic bacteria and at the same time hampers the activity of methanogenic archaea (Whalen 2005). Furthermore, Epp and Chanton (1993) suggested that 10-90\% of $\mathrm{CH}_{4}$ produced is oxidized by methanotrophic bacteria in the rhizosphere of vascular plants. Thus, the negative relationship found between $\mathrm{CH}_{4}$ and oxygen pore water concentrations might result from both $\mathrm{CH}_{4}$ oxidation and plant-mediated transport. Similarly, King et al. (1998) reported an inverse correlation between $\mathrm{CH}_{4}$ pore water concentration and root density, where low $\mathrm{CH}_{4}$ pore water concentrations were measured at depths of 15-20 cm in zones of high root densities.

\section{Conclusion}

The objective of this study was to quantify the $\mathrm{CH}_{4}$ emissions from fens located in the Swiss Alps at 1,800-2,600 $\mathrm{m}$ a.s.l. The emissions ranged from 74 to $711 \mathrm{mg} \mathrm{CH}_{4} \mathrm{~m}^{-2} \mathrm{day}^{-1}$ and thus were in the same range as emissions from wetlands in northern latitudes (Alaska, Siberia, and northern Canada). Despite the fact that $\mathrm{CH}_{4}$ emissions showed high spatial variability within and between the different sites the emissions could be related to environmental factors, such as bedrock type, plant biomass and $\mathrm{CH}_{4}$ pore water concentration at shallow depths. However, since these environmental factors may be interdependent further study would be required to determine if they have a direct or an indirect effect. This study also demonstrates the importance of aerenchymous plants like Carex spp. These plants not only provide carbon substrates for the methanogenic archaea and oxygen for the methanotrophic bacteria in the subsurface but also act as major conduits for the transport of $\mathrm{CH}_{4}$ from the subsurface into the atmosphere.

Acknowledgments We thank A. Gauer, M. Vogt and É. Mészáros for their assistance in the laboratory and the field, as well as J. Schneller for botanical determinations. We are grateful 
to Kraftwerke Oberhasli AG (KWO) and Centralschweizerische Kraftwerke (CKW) for facilitating access to the field sites at Oberaar and Göschener Alp, respectively. Additionally, we acknowledge A. Lazzaro, R. Henneberger, B. Morris, and C. Hoffman for helpful comments on the manuscript. ETH Zurich supported this work.

\section{References}

Armstrong W, Justin SHFW, Beckett PM, Lythe S (1991) Root adaptation to soil waterlogging. Aquat Bot 39:57-73

Bagshaw EA, Wadham JL, Mowlem M, Tranter M, Eveness J, Fountain AG, Telling J (2011) Determination of dissolved oxygen in the cryosphere: a comprehensive laboratory and field evaluation of fiber optic sensors. Environ Sci Technol 45:700-705

Bardgett RD, Freeman C, Ostle NJ (2008) Microbial contribution to climate change through carbon cycle feedbacks. ISME J 2:805-814

Bartlett KB, Crill PM, Sass RL, Harriss RC, Dise NB (1992) Methane emissions from tundra environments in the Yukon-Kuskokwin Delta, Alaska. J Geophys Res Atmos 97:16645-16660

Bates D, Maechler M, Bolker B (2011) lme4: Linear mixed-effect model using S4 classes. R package version 0.999375-39. http:// CRAN.R-project.org/package0lme4. Accessed Dec 2012

Beer J, Blodau C (2007) Transport and thermodynamics constrain belowground carbon turnover in a northern peatland. Geochim. Cosmochim. Acta 71:2989-3002

Bellisario LM, Bubier JL, Moore TR, Chanton JP (1999) Controls on $\mathrm{CH}_{4}$ emissions from a northern peatland. Glob Biogeochem Cycles 13:81-91

Bridgham SD, Cadillo-Quiroz H, Keller JK, Zhuang QL (2013) Methane emissions from wetlands: biogeochemical, microbial, and modeling perspective from local to global scales. Glob Chang Biol 19:1325-1346

Bubier JL, Moore TR, Roulet NT (1993) Methane emissions from wetlands in the mid-boreal region of northern Ontario, Canada. Ecology 74:2240-2254

Bubier JL, Moore TR, Juggins S (1995a) Predicting methane emission from bryophyte distribution in Northern Canadian Peatlands. Ecology 76:677-693

Bubier JL, Moore TR, Bellisario L, Comer NT (1995b) Ecological controls on methane emissions from a northern peatland complex in the zone of discontinuous permafrost, Mannitoba, Canada. Glob Biogeochem Cycles 9:455-470

Cao GM, Xu XL, Long RJ, Wang QL, Wang CT, Du YG, Zhao XQ (2008) Methane emissions by alpine plant communities in the Qinghai-Tibet plateau. Biol Lett 4:681-684

Chapman JB, Lewis B, Litus G (2003) Chemical and isotopic evaluation of water sources to the fens of the south park, Colorado. Environ Geol 43:533-545

Chasar LS, Chanton JP, Glaser PH, Siegel DI (2000) Methane concentration and stable isotope distribution as evidence of rhizospheric processes: comparison of a fen and bog in the glacial lake agassiz peatland complex. Ann Bot 86:655-663

Chen H, Wu N, Gao YH, Wang YF, Luo P, Tian JQ (2009) Spatial variations on methane emissions from zoige alpine wetlands of southwest China. Sci Total Environ 407: 1097-1104

Chen HA, Wu N, Wang YF, Gao YH, Peng CH (2011) Methane fluxes from alpine wetlands of Zoige Plateau in relation to water regime and vegetation under two scales. Water Air Soil Pollut 217:173-183

Chimner RA, Cooper DJ (2003) Carbon dynamics of pristine and hydrologically modified fens in the southern Rocky Mountains. Can J Bot 81:477-491

Christensen TR, Jonasson S, Callaghan TV, Havstrom M (1995) Spatial variation in high-latitude methane flux along a transect across Siberian and European tundra environments. J Geophys Res Atmos 100:21035-21045

Christensen TR, Ekberg A, Ström L, Mastepanov M, Panikov N, Öquist M, Svensson BH, Nykänen H, Martikainen PJ, Oskarsson H (2003) Factors controlling large scale variations in methane emissions from wetlands. Geophys Res Lett 30:1414-1418

Conrad R (1996) Soil microorganisms as controllers of atmospheric trace gases $\left(\mathrm{H}_{2}, \mathrm{CO}, \mathrm{CH}_{4}, \mathrm{OCS}, \mathrm{N}_{2} \mathrm{O}\right.$, and $\left.\mathrm{NO}\right)$. Microbiol Rev 60:609-640

Denman KL, Brasseur A, Chidthaisong A, Ciais P, Cox PM, Dickinson RE, Hauglustaine DA, Heinze C, Holland E, Jacob D, Lohmann U, Ramachandran S, da Silva Dias PL, Wofsy SC, Zhang X (2007) Couplings 1 between changes in the climate system and biogeochemistry. climate change 2007: the physical science basis. Contribution of Working Group I to the fourth assessment report of the intergovernmental panel on climate change

Ding WX, Cai ZC, Wang DX (2004) Preliminary budget of methane emissions from natural wetlands in China. Atmos Environ 38:751-759

Ding WX, Cai ZC, Tsuruta H (2005) Plant species effects on methane emissions from freshwater marshes. Atmos Environ 39:3199-3207

Dise NB, Gorham E, Verry ES (1993) Environmental factors controlling methane emissions from peatlands in northern Minnesota. J Geophys Res Atmos 98:10583-10594

Dunfield P, Knowles R, Dumont R, Moore TR (1993) Methane production and consumption in temperate and subarctic peat soils: response to temperature and $\mathrm{pH}$. Soil Biol Biochem 25:321-326

Epp MA, Chanton JP (1993) Rhizospheric methane oxidation determined via the methyl fluoride inhibition technique. J Geophys Res 98:18422-18423

Fechner EJ, Hemond HF (1992) Methane transport and oxidation in the unsaturated zone of a Sphagnum peatland. Glob Biogeochem Cycles 6:33-44

Franchini AG, Zeyer J (2012) Freeze-coring method for characterization of microbial community structure and function in wetland soils at high spatial resolution. Appl Environ Microbiol 78:4501-4504

Freeman C, Lock MA, Reynolds B (1992) Fluxes of $\mathrm{CO}_{2}, \mathrm{CH}_{4}$ and $\mathrm{N}_{2} \mathrm{O}$ from a Welsh peatland following simulation of water table draw-down: potential feedback to climate change. Biogeochemistry 19:51-60

Freeman C, Nevison GB, Kang H, Hughes S, Reynolds B, Hudson JA (2002) Contrasted effects of simulated drought on the production and oxidation of methane in a mid-Wales Wetland. Soil Biol Biochem 34:61-67 
Frenzel P, Karofeld E (2000) $\mathrm{CH}_{4}$ emission from a hollow-ridge complex in a raised bog: the role of $\mathrm{CH}_{4}$ production and oxidation. Biogeochemistry 51:91-112

Gorham E (1991) Northern peatlands: role in the carbon cycle and probable responses to climatic warming. Ecol Appl 1:182-195

Green SM, Baird AJ (2013) The importance of episodic ebullition methane losses from three peatland microhabitats: a controlled-environment study. Eur J Soil Sci 64:27-36

Heyer J, Berger U, Kuzin IL, Yakovlev ON (2002) Methane emissions from different ecosystem structures of the subarctic tundra in Western Siberia during midsummer and during the thawing period. Tellus B 54:231-249

Hirota M, Tang YH, Hu QW, Hirata S, Kato T, Mo WH, Cao GM, Mariko S (2004) Methane emissions from different vegetation zones in a Qinghai-Tibetan plateau wetland. Soil Biol Biochem 36:737-748

Hornibrook ERC, Bowes HL, Culbert A, Gallego-Sala AV (2009) Methanotrophy potential versus methane supply by pore water diffusion in peatlands. Biogeosciences 6:1490-1504

Joabsson A, Christensen TR (2001) Methane emissions from wetlands and their relationship with vascular plants: an Arctic example. Glob Chang Biol 7:919-932

Joabsson A, Christensen TR, Wallen B (1999) Vascular plant controls on methane emissions from northern peatforming wetlands. Trends Ecol Evol 14:385-388

Johnson JB, Omland KS (2004) Model selection in ecology and evolution. Trends Ecol Evol 19:101-108

King JY, Reeburgh WS, Regli SK (1998) Methane emission and transport by arctic sedges in Alaska: results of a vegetation removal experiment. J Geophys Res Atmos 103:29083-29092

Kleikemper J, Pombo SA, Schroth MH, Sigler WV, Pesaro M, Zeyer J (2005) Activity and diversity of methanogens in a petroleum hydrocarbon-contaminated aquifer. Appl Environ Microbiol 71:149-158

Koch O, Tscherko D, Kandeler E (2007) Seasonal and diurnal net methane emissions from organic soils of the eastern alps, Austria: effects of soil temperature, water balance, and plant biomass. Arct Antarct Alp Res 39:438-448

Lai DYF (2009) Methane dynamics in northern peatlands: a review. Pedosphere 19:409-421

Lazzaro A, Abegg C, Zeyer J (2009) Bacterial community structure of glacier forefields on siliceous and calcareous bedrock. Eur J Soil Sci 60:860-870

Lerman A (1979) Geochemical processes: water and sediment environments. Wiley, New York

Letts MG, Roulet NT, Comer NT, Skarupa MR, Verseghy DL (2000) Parametrization of peatland hydraulic properties for the Canadian land surface scheme. Atmos Ocean 38:141-160

Liebner S, Schwarzenbach SP, Zeyer J (2012) Methane emissions from an alpine fen in central Switzerland. Biogeochemistry 109:287-299

Limpens J, Berendse F, Blodau C, Canadell JG, Freeman C, Holden J, Roulet N, Rydin H, Schaepan-Strub G (2008) Peatlands and the carbon cycle: from local processes to global implications-a synthesis. Biogeosciences 5:1475-1491
Mast MA, Wickland KP, Striegl RG, Clow DW (1998) Winter fluxes of $\mathrm{CO}_{2}$ and $\mathrm{CH}_{4}$ from subalpine soils in rocky mountain national park, Colorado. Glob Biogeochem Cycles 12:607-620

Moore TR, Basiliko N (2006) Decomposition in boreal peatlands. In: Wieder RK, Vitt DH (eds) Boreal peatland ecosystems. Ecological studies 188. Springer, Berlin, pp 125-144

R Development Core Team (2012) R: a language and environment for statistical computing. R Foundation for Statistical Computing, Vienna, Austria. ISBN 3-900051-07-0, http:// www.R-project.org/. Accessed Dec 2012

Roura-Carol M, Freeman C (1999) Methane release from peat soils: effect of Sphagnum and Juncus. Soil Biol Biochem 31:323-325

Rydin H, Jeglum JK (2006) The biology of peatlands. Oxford University Press, Oxford

Saarnio S, Morero M, Shurpali NJ, Tuittila ES, Makila M, Alm J (2007) Annual $\mathrm{CO}_{2}$ and $\mathrm{CH}_{4}$ fluxes of pristine boreal mires as a background for the lifecycle analyses of peat energy. Boreal Environ Res 12:101-113

Sachs T, Giebels M, Boike J, Kutzbach L (2010) Environmental controls on $\mathrm{CH}_{4}$ emission from polygonal tundra on the microsite scale in the lena river delta, Siberia. Glob Chang Biol 16:3096-3110

Schimel JP (1995) Plant transport and methane production as controls on methane flux from arctic wet meadow tundra. Biogeochemistry 28:183-200

Sebacher DI, Harriss RC, Bartlett KB, Sebacher SM, Griche SS (1986) Atmospheric methane sources: Alaskan tundra bogs, an alpine fen, and subarctic boreal marsh. Tellus B 38:1-10

Ström L, Ekberg A, Mastepanov M, Christensen TR (2003) The effect of vascular plants on carbon turnover and methane emissions from a tundra wetland. Glob Chang Biol 9:1185-1192

Trudeau NC, Garneau M, Pelletier L (2013) Methane fluxes from a patterned fen of the northeastern part of the La grande river watershed, james bay, Canada. Biogeochemistry 113:409-422

Turunen J, Tomppo E, Tolonen K, Reinikainen A (2002) Estimating carbon accumulation rates of undrained mires in Finland-application to boreal and subarctic regions. Holocene 12:69-80

Valentine DW, Holland EA, Schimel DS (1994) Ecosystem and physiological controls over methane production in northern wetlands. J Geophys Res 99:1563-1571

van der Nat FJWA, Middelburg JJ (1998) Seasonal variation in methane oxidation by the rhizosphere of Phragmites australis and Scirpus lacustris. Aquat Bot 61:95-110

Visser EJW, Bögemann GM, van de Steeg HM, Pierik R, Blom CWPM (2000) Flooding tolerance of Carex species in relation to field distribution and aerenchyma formation. New Phytol 148:93-103

von Fischer JC, Rhew RC, Ames GM, Fosdick BK, von Fischer PE (2010) Vegetation height and other controls of spatial variability in methane emissions from the arctic coastal tundra at barrow, Alaska. J Geophys Res Biogeosci 115: G00I03

Waddington JM, Roulet NT (2000) Carbon balance of a boreal patterned peatland. Glob Change Biol 6:87-97 
Waddington JM, Roulet NT, Swanson RV (1996) Water table control of $\mathrm{CH}_{4}$ emission enhancement by vascular plants in boreal peatlands. J Geophys Res 101:22775-22785

Wagner D, Kobabe S, Pfeiffer EM, Hubberten HW (2003) Microbial controls on methane fluxes from a polygonal tundra of the lena delta, Siberia. Permafr Periglac 14: 173-185

West AE, Brooks PD, Fisk MC, Smith LK, Holland EA, Jaeger CH, Babcock S, Lai RS, Schmidt SK (1999) Landscape patterns of $\mathrm{CH}_{4}$ fluxes in an alpine tundra ecosystem. Biogeochemistry 45:243-264

Whalen SC (2005) Biogeochemistry of methane exchange between natural wetlands and the atmosphere. Environ Eng Sci 22:73-94
Whalen SC, Reeburgh WS (1992) Interannual variation in tundra methane emission: a 4 years time series at fixed sites. Glob Biogeochem Cycles 6:139-159

Whalen SC, Reeburgh WS (2000) Methane oxidation, production, and emission at contrasting sites in a boreal bog. Geomicrobiol J 17:237-251

Whiting GJ, Chanton JP (1992) Plant-dependent $\mathrm{CH}_{4}$ emission in a subartic Canadian fen. Glob Biogeochem Cycles 6:225-231

Whiting GJ, Chanton JP (1993) Primary production control of methane emission from wetlands. Nature 364:794-795

Wickland KP, Striegl RG, Mast MA, Clow DW (2001) Carbon gas exchange at a southern Rocky Mountain wetland, 1996-1998. Glob Biogeochem Cycles 15:321-335 